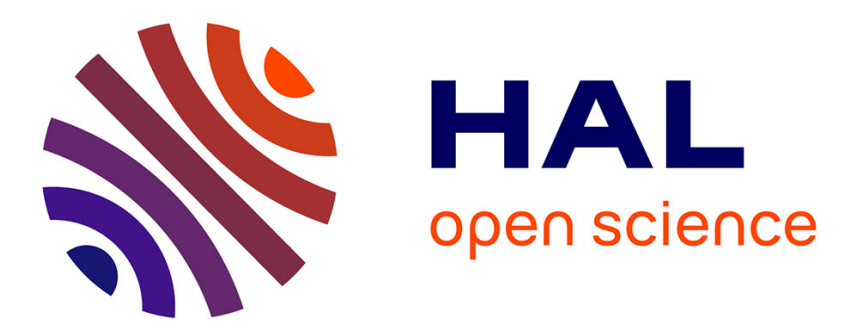

\title{
Towards a better control of dairy powder rehydration processes
}

\author{
Bruno Richard, Jean-Francois Le Page, Pierre Schuck, Christophe André, \\ Romain Jeantet, Guillaume Delaplace
}

\section{To cite this version:}

Bruno Richard, Jean-Francois Le Page, Pierre Schuck, Christophe André, Romain Jeantet, et al.. Towards a better control of dairy powder rehydration processes. International Dairy Journal, 2013, 31, pp.18-28. 10.1016/j.idairyj.2012.07.007 . hal-01209412

\section{HAL Id: hal-01209412 \\ https://hal.science/hal-01209412}

Submitted on 29 May 2020

HAL is a multi-disciplinary open access archive for the deposit and dissemination of scientific research documents, whether they are published or not. The documents may come from teaching and research institutions in France or abroad, or from public or private research centers.
L'archive ouverte pluridisciplinaire HAL, est destinée au dépôt et à la diffusion de documents scientifiques de niveau recherche, publiés ou non, émanant des établissements d'enseignement et de recherche français ou étrangers, des laboratoires publics ou privés. 


\title{
Towards a better control of dairy powder rehydration processes
}

\author{
B. Richard ${ }^{\text {a }}$, J.F. Le Page ${ }^{\text {a }}$, P. Schuck ${ }^{\text {b,c }}$, C. Andre ${ }^{\text {a,d }}$, R. Jeantet ${ }^{\text {b,c }}$, G. Delaplace ${ }^{\mathrm{a}, *}$ \\ a INRA-PIHM, F-59651 Villeneuve d'Ascq, France \\ ${ }^{\mathrm{b}}$ INRA, UMR1253, F-35000 Rennes, France \\ ${ }^{\mathrm{c}}$ Agrocampus Ouest, UMR1253, F-35000 Rennes, France \\ d HEI, F-59000 Lille, France
}

\section{A R T I C L E I N F O}

\section{Article history:}

Received 9 December 2011

Received in revised form

1 June 2012

Accepted 17 July 2012

\begin{abstract}
A B S T R A C T
The present study investigated the effect of flow conditions (temperature, agitators and stirring speed) on particle size reduction during the reconstitution process of milk powders. Images acquired with a granulomorphometer during reconstitution showed that the mixing system design had a strong influence on the course of the rehydration process. Laser light scattering data obtained for each temperature of reconstitution and agitator revealed that whatever the powder tested, the number of agitator revolutions required to achieve a given level of rehydration was constant and independent of the stirring speed. Kinetics of rehydration were shown to be much more sensitive to temperature than to stirring speed. Inversely, as expected, it was shown that granulation did not always improve rehydration time, depending on surface composition. This result revealed that both granulation/composition and flow should be considered in controlling the reconstitution process.
\end{abstract}

(c) 2012 Elsevier Ltd. All rights reserved.

\section{Introduction}

Today, dairy ingredients are increasingly used throughout the food industry. One of the approaches used to facilitate transport and storage is to convert dairy liquids into powders by spray drying (Schuck, 2002). In a further step, the powders are reconstituted to supplement fresh milk in dairy manufacture and then transformed with various processing equipment to obtain milk products with different functional properties (e.g., gelling, foaming or nutritional properties; Aneja, 1990).

Reconstitution is usually realised in mechanically agitated tanks. Ideally, the process should be as fast as possible and should require a minimum input of energy. The resultant reconstituted product should be devoid of lumps (Jensen \& Nielsen, 1982). These requirements are common to both industry and consumers, but difficult to fully satisfy (Cayot \& Lorient, 1998; King, 1966; Schubert, 1993).

With regard to process complexity, knowledge of powder rehydration is still insufficient. Many models exist on the kinetics of dissolution, sometimes semi-empirical, sometimes mechanistically realistic (diffusion, swelling, erosion/degradation), but the analysis of particle hydration shows significant differences between theory

\footnotetext{
* Corresponding author. Tel.: +33 320435426.

E-mail address: guillaume.delaplace@lille.inra.fr (G. Delaplace).
}

and experimental values (Jeantet, Schuck, Six, Andre, \& Delaplace, 2010). Potentially, influencing parameters are too numerous to consider (Siepmann \& Siepmann, 2008).

In this work, an attempt has been made to better understand the mechanisms of hydration; namely the effect of stirring speed, of geometry of the mixing device, of temperature of the solvent, of composition and of structure (granulated or not) of the powder, were investigated.

Many observations have been made on the structure of the ingredients that compose a powder, but knowledge of these structural arrangements is not yet sufficient to properly explain the different rehydration kinetics observed. Jeantet et al. (2010) established a relationship between the number of impeller revolutions in agitated vessels and the degree of rehydration of the powder. This correlation was ascertained for one micellar casein powder only and a limited range of process conditions (one mixing system and a range of impeller rotational speeds). The generic feature of this relationship and its domain of validity needed to be better defined by investigating possible extension to a larger process parameters range (mixing equipment and agitator speed) and applicability to other powders. In addition, there is a lack of in situ information on the successive steps occurring during the powder rehydration process; in previous publications, the rehydration process was usually monitored through the reduction in the size of powder particles measured on samples by laser granulometry (static light scattering, SLS), without visual observation of 
the morphological aspect of dispersed and continuous phases during the course of rehydration.

The aim of this contribution was to begin to fill this gap, by first determining the influence of rehydration conditions (stirrer speed and mixing systems, temperature of the agitated suspension) on dairy powder dissolution time. The influence of the composition and structure (granulation or not) of the powder on rehydration kinetics were also studied. Powders with slow and fast dissolution kinetics were used for this purpose, using various ingredients (lactose, whey protein, native phosphocaseinate). The time to achieve a certain degree of size reduction was determined through SLS analysis of samples during the course of the rehydration process.

Simultaneously, digital images of powder during dissolution were obtained using a commercial granulomorphometer. Digital image analyses were performed to visualise solvent penetration inside powders and to better understand the associated fragmentation mechanisms.

Rehydration times, solvent penetration mechanisms and fragmentation are discussed with regard to rehydration conditions and dairy powder type.

\section{Materials and methods}

\subsection{Powders}

\subsubsection{Dairy powders}

Four different dairy concentrates were prepared specifically for this study by spray drying, so as to obtain various powders with different rehydration properties. A pilot plant spray dryer (GEA, Niro Atomizer, Montigny le Bretonneux, France) was used for this purpose. The atomiser was equipped with a pressure nozzle (0.73 $\mathrm{mm}$ diameter orifice) and a 4-slot core $(0.51 \mathrm{~mm}$ nominal width), providing a $60^{\circ}$ spray angle; the pressure pump (16 MPa) was supplied by Gea-Niro-Soavi (Copenhaguen, Denmark). The evaporation capacity of the plant was $70-120 \mathrm{~kg} \mathrm{~h}^{-1}$.

To obtain granulated powder $(G)$, fine particles were recycled within the spraying cone according to Jeantet, Ducept, Dolivet, Méjean, and Schuck (2008). Agglomeration occurred between particles so as to form a larger diameter than that of the nongranulated powder (NG).

Two types of concentrate were used: a native phosphocaseinate (NPC) concentrate that is slow to rehydrate after spray drying (Gaiani, Banon, Scher, Schuck, \& Hardy, 2006; Gaiani, Schuck, Scher, Desobry, \& Banon, 2007; Schuck et al., 1994); and a whey protein isolate concentrate with fast rehydration kinetics. The term 'native' is used to indicate undenatured phosphocaseinate, very close to initial state. In this study, evidence was provided that spray drying induces a very rapid heating, inducing only slight protein denaturing, as seen by the absence of insoluble aggregates during powder rehydration.

The initial NPC (Promilk 872 B1) was provided by Ingredia (Arras, France) and obtained from $0.1 \mu \mathrm{m}$ membrane tangential microfiltration of skimmed milk followed by spray drying (Pierre, Fauquant, le Graet, Piot, \& Maubois, 1992; Schuck et al., 1994). The whey protein isolate (WPI), Prolacta, was provided by Lactalis Ingrédient (Bourgbarré, France) and obtained by ultrafiltration and diafiltration of the microfiltration permeate ("ideal whey") collected during NPC production.

Apart from the NPC and WPI, the two other concentrates resulted from a mixture of lactose or WPI with NPC. Precisely, the 2 concentrates were: NPC/lactose powder (70/30; w/w) and NPC/WPI powder $(80 / 20 ; w / w)$. The pure monohydrated $\alpha$-lactose was provided by Lactalis (Lactosérum France, Baleycourt, France).

The powders obtained were stored at $4{ }^{\circ} \mathrm{C}$ in hermetic bags. One hour before the rehydration test, the necessary amount was equilibrated at room temperature.

\subsubsection{Physico-chemical analysis}

Various physico-chemical analyses were performed on the 8 powders resulting from the spray drying of the 4 concentrates under different operating conditions (with or without recycling of fine particles). Ash, casein, whey protein and non protein nitrogen, noncasein Nitrogen, lactose content, dry total solids, powder particle size and true density were determined for each powder.

The total solids amount was calculated by weight loss after drying a sample of the powder mixed with sand in a forced air oven at $105{ }^{\circ} \mathrm{C}$ for $5 \mathrm{~h}$. Casein, whey protein and non protein nitrogen contents were determined according to Aschaffenburg and Drewry (1959) and Rowland (1938). The lactose content was determined by enzymatic reactions (Boehringer, Ingelheim am Rhein, Germany). The ash content was measured after incineration at $550{ }^{\circ} \mathrm{C}$ for $5 \mathrm{~h}$. True density was measured using gas pycnometry with both helium and nitrogen, on a Pycnometry ATC (Thermo Fisher Scientific, Courtaboeuf, France). The chemical composition of the powders (NPC, WPI, NPC/lactose and NPC/WPI) in their granulated or non-granulated form $(G, N G)$ is reported in Table 1. Dry particle sizes were measured by laser granulometry.

\subsection{Powder particle analysis}

In this work, two complementary techniques were used to follow the morphological parameters of dispersed particles all along the rehydration process: SLS (determination of mean particle size) and granulomorphometry (particles number, solvent penetration into the core of particle, shape of particle).

Table 1

Chemical composition of the dairy powders (granulated and non-granulated). ${ }^{a}$

\begin{tabular}{|c|c|c|c|c|c|c|c|c|c|c|}
\hline \multirow[t]{2}{*}{ Powders } & \multicolumn{8}{|c|}{ Content (g $100 \mathrm{~g}^{-1}$ powder) } & \multirow[t]{2}{*}{ Size $(\mu \mathrm{m})$} & \multirow[t]{2}{*}{ Density $\left(\mathrm{kg} \mathrm{m}^{-3}\right)$} \\
\hline & Total solids & Protein & Casein & Whey protein & $\mathrm{NCN}$ & NPN & Ash & Water & & \\
\hline \multicolumn{11}{|l|}{ Granulated } \\
\hline NPC & 96.9 & 86.2 & 79.6 & 6.2 & 6.6 & 0.4 & 8.3 & 3.1 & 245 & 1127 \\
\hline WPI & 97.2 & 93.7 & - & 77.8 & 78.4 & 0.6 & 2.1 & 2.8 & 166 & 1289 \\
\hline NPC/WPI & 96.9 & 86.9 & 62.2 & 24.1 & 24.7 & 0.6 & 7.1 & 3.1 & 211 & 1127 \\
\hline NPC/lactose & 96.9 & 66.1 & 61.3 & 4.5 & 4.9 & 0.4 & 6.4 & 3.1 & 225 & 1226 \\
\hline \multicolumn{11}{|c|}{ Non-granulated } \\
\hline NPC & 95.3 & 85.6 & 79.4 & 5.8 & 6.3 & 0.4 & 8.4 & 4.7 & 49 & 1196 \\
\hline WPI & 95.0 & 93.3 & - & 79.1 & 79.7 & 0.7 & 2.2 & 5.0 & 26 & 1298 \\
\hline NPC/WPI & 95.5 & 87.5 & 63.2 & 23.6 & 24.2 & 0.6 & 7.1 & 4.5 & 38 & 1253 \\
\hline NPC/lactose & 95.4 & 67.1 & 62.3 & 4.4 & 4.8 & 0.4 & 6.5 & 4.6 & 35 & 1236 \\
\hline
\end{tabular}

\footnotetext{
a Abbreviations are: NPC, native phosphocaseinate; WPI, whey protein isolate; NCN, noncasein nitrogen; NPN, non protein nitrogen.
} 


\subsubsection{Granulomorphometry}

Digital images of powder particles were obtained during the course of rehydration, using a granulomorphometer, which here refers to the commercial name of the apparatus developed by Occhio (Angleur, Belgium) to acquire high quality pictures of particles dispersed in solvent using a microscopic technique, and the associated image analysis software (Fig. 1).

The microscopic technique consists of pumping a sample of the solid/liquid suspension into a flow-cell of prescribed width and obtaining digital high resolution pictures. In the following part, the use of the granulomorphometer is detailed; complementary information concerning this device is given in Petit et al. (2012).

In this work, both particle number and size of the samples were analysed using the Flow-Cell 200 S-M. The width of the flow-cell was $300 \mu \mathrm{m}$, and magnification was $6 \times$ corresponding to $0.58 \mu \mathrm{m}$ per pixel. Moreover, sample pictures were acquired when the flow was completely stopped so as to avoid blur on the obtained digital pictures. Since the powder concentration used in the rehydration test was too high for direct measurement, it was necessary to dilute before analysis. The dilution was made automatically and was the same for all the rehydration tests.

The digital images obtained were analysed with Callisto ${ }^{\circledR}$ software (Angleur, Belgium) to count the number of particles per picture, to measure their size distribution by using greyscale level differences between the particle and the background and to deduce the morphological characteristics of the powder particles (area, perimeter or circularity). Light calibration was realised on the solvent, with an associated grey level of 200 (being the value 0 for black). Powder particles were not fully black, as a homogenous mineral powder, but appeared generally with white to grey shade: the periphery was well defined in grey (more or less dark) and the inner was marbled, making it difficult to adjust the threshold at initial state. Each pixel on the pictures taken, with a value less than the threshold defined on the greyscale, was analysed by the software. It used the greyscale to pinpoint particles, then calculated various morphological parameters (inner diameter, area diameter, circularity, length, bluntness). The most accurate measurements were obtained with a 165 threshold for particle detection as seen in numerous preliminary tests, by comparison with SLS analysis.

The principal morphological parameter of this study is the inner diameter. The inner diameter was defined as the equivalent diameter of a sphere circumscribed by the analysed particle. This was preferred to the area diameter, i.e., the diameter of an equivalent sphere having the same apparent area as the particle, which overestimates diameter. The mean particle diameter (Dv50) was calculated by averaging the inner diameter of all analysed particles.

Particle number and size distribution were determined by processing at least ten pictures, which corresponded to approximately 10,000 particles, depending on the powder and operating parameters (i.e., initial mean size of dry powder particles that influences the number of particles per gram). Each analysis during rehydration was controlled by the two analysis technique (granulomorphometer and SLS analysis).

\subsubsection{Static light scattering}

The granulometric distribution was determined by laser light scattering using a MasterSizer 2000 (Malvern Instruments, Malvern, Worcestershire, UK) equipped with a $5 \mathrm{~mW}$ He-Ne laser operating at a wavelength of $633 \mathrm{~nm}$. Samples were diluted into the Malvern cell (volume: $100 \mathrm{~mL}$ ) with distilled water to reach appropriate obscuration (25\%). Refractive indexes for solvent, particle and adsorption were respectively $1.33,1.3$ and 0.1 . These indexes are recommended by manufacturer (Malvern).

The class size limits were $0.02-2000 \mu \mathrm{m}$ Dv50 was used to estimate size reduction during rehydration.

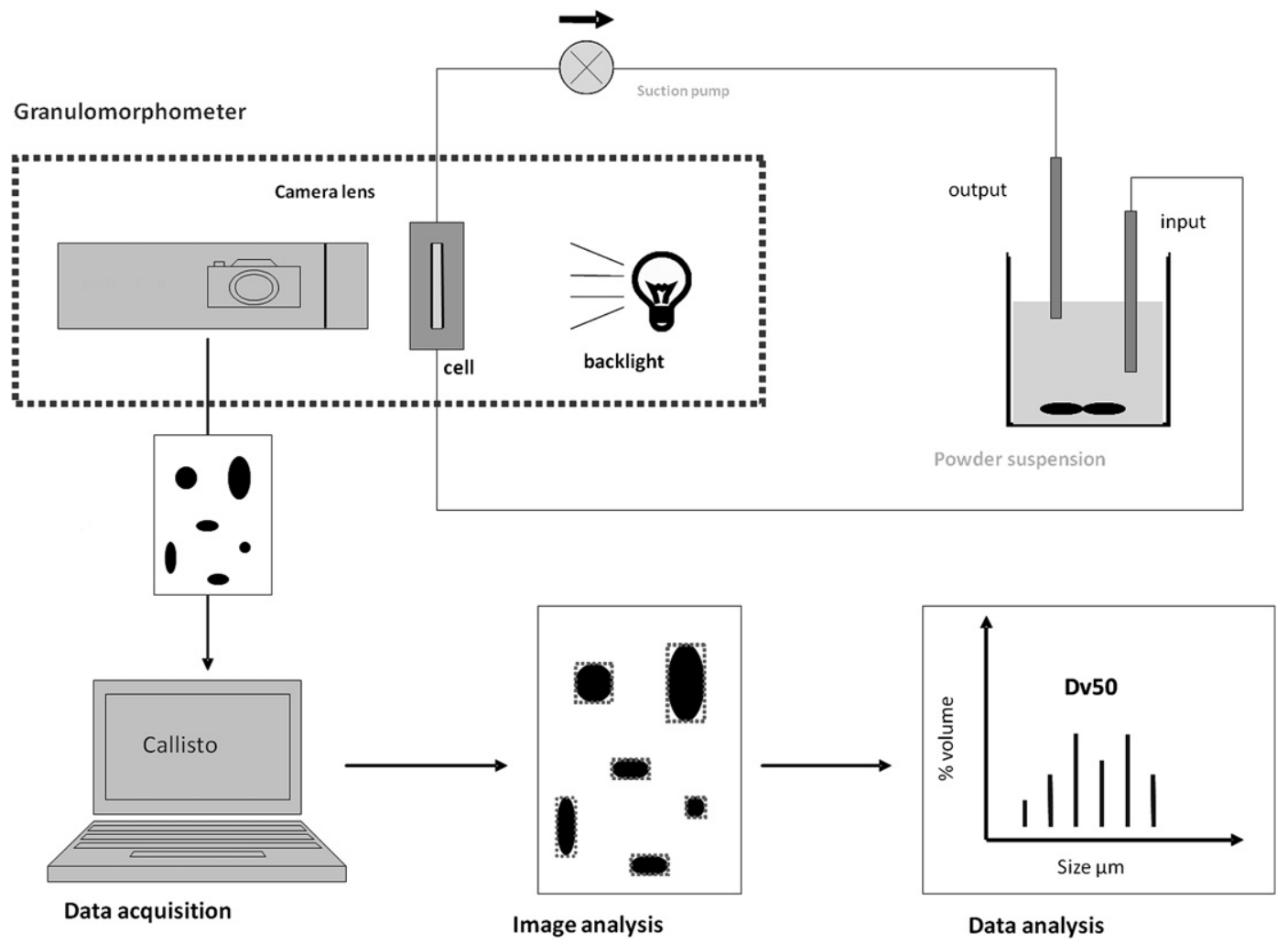

Fig. 1. Operating diagram of granulomorphometer. 


\subsection{Rehydration test}

The rehydration experiments were carried out using a $3.5 \mathrm{~L}$ jacketed glass vessel ( $16 \mathrm{~cm}$ diameter) equipped with one baffle to limit vortex formation (Fig. 2A), as described by Jeantet et al. (2010). Two impellers were studied, the first agitator (impeller $1 ; 8 \mathrm{~cm}$ diameter, Fig. 2B) was a 6-pitched-blade impeller, the second (impeller 2; $8 \mathrm{~cm}$ diameter, Fig. 2C) consisted of two propellers (airscrew) distant from $5 \mathrm{~cm}$ with two blades arranged at right angles; both impellers were vertically, centrally mounted. The influence of impeller rotational speed $(N ; \mathrm{rpm})$ was studied within the range of 500-900 rpm; and temperature range $\left(25^{\circ} \mathrm{C}\right.$ and $30{ }^{\circ} \mathrm{C} \pm 0.5{ }^{\circ} \mathrm{C}$, depending on the experiments). The solid/liquid concentration was set at $8 \%(\mathrm{w} / \mathrm{w})$.

$T_{0}$ corresponds to the powder insertion. The impeller speed was set at $1200 \mathrm{rpm}$ during the first $45 \mathrm{~s}$ of insertion to reduce insertion time and to establish a constant wetting time for all powders, and then it was put back to the desired speed. The monitoring of granulometric distribution started immediately after by sampling $0.5 \mathrm{~mL}$ of powder suspension for SLS analysis and by an automatic dilution for granulomorphometrics. The automatic dilution loop included two peristaltic pumps (one for the sample, one for distilled water). It was checked that these pumps did not affect particle features (shape, appearance, fragmentation, number). The manual sampling was carried out with a $16 \mathrm{~mm}$ diameter syringe, type BD Discardit II (Becton Dickinson, Le Pont de Claix, France), located halfway between the liquid surface and the vessel bottom and about halfway between the vessel wall and the paddle shaft to limit the presence of foam in samples. The size measurements were made initially every $3 \mathrm{~min}$, increasing to $5 \mathrm{~min}$ and then $15 \mathrm{~min}$, respectively, after $25 \mathrm{~min}$ and $45 \mathrm{~min}$ of rehydration. It was then reduced again to $3 \mathrm{~min}$ when the Dv50 fell below $15 \mu \mathrm{m}$, the decrease in size becoming faster after that threshold. The time between two measurements depended on the speed of powder

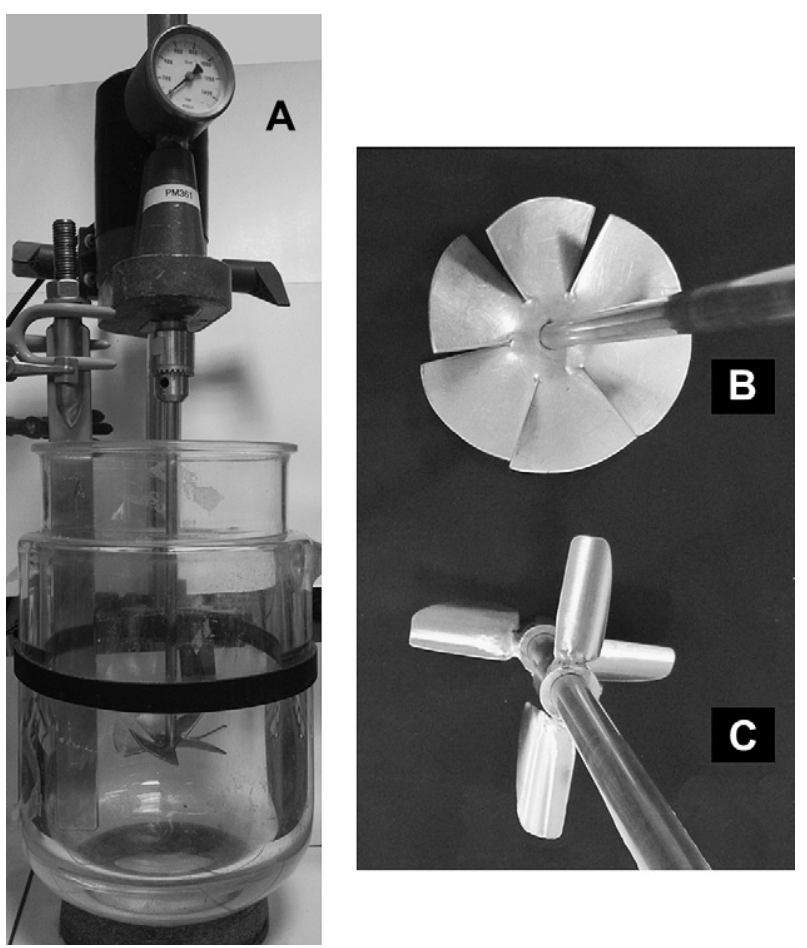

Fig. 2. Experimental rehydration device: A, 3.5 L jacketed glass vessel; B, six-pitchedblade impeller; C, two propellers with right angled arrangement. rehydration powder: the faster the kinetics, the more frequent the measurements. The reproducibility of the results was estimated by repeating experiments. An example is given in Fig. 3: white squares show the kinetics of rehydration of the NPC/WPI non-granulated powder (in triplicate), at $700 \mathrm{rpm}, 25^{\circ} \mathrm{C}$ with impeller 1 .

On average, size measurements were accurate to about $1 \mu \mathrm{m}$. The accuracy on the rehydration time total was less than $10 \%$ (measured on different replicates of rehydration). Given the limited amount of powder and the significant amount used for each rehydration, for each parameter studied, the repetition is usually done in case of doubt on the values obtained. However, most of the data were measured twice.

Size reduction kinetics are described by evolution of Dv50 with time and kinetics performed of other parameters. The images obtained with the granulomorphometer provide insight into the phenomena observed. The powders are fairly comparable, given the parameters considered (mainly speed and temperature), the resulting images were quite similar.

Systematically, a post manual processing was performed to eliminate scatters contained in the digital images (as presence of air bubbles or particles superposition). This was done to make sure the automatic image analysis process, and the Dv50 computation.

\subsection{Dissolution time determination: total rehydration time}

Particle size distribution measured by SLS was used to determine rehydration time for each test. Dv50, extracted from the particle size distributions, was plotted as a function of time. Fig. 3 shows a typical rehydration curve obtained by the SLS method.

As expected, Dv50 decreased with time and reached an asymptotic value close to the mean diameter of casein micelles, $0.2 \mu \mathrm{m}$. The powder size reduction just before reaching this value was quite marked and consequently the criterion of achieving micellar size was appropriate to define total powder rehydration time. Consequently, total rehydration time was defined as the time required after powder incorporation for Dv50 to reach $0.2 \mu \mathrm{m}$ (Fig. 3, the cross symbol at 260 min corresponds to micellar size). Note that although a decrease in particle size with time is also observed in granulomorphometry analysis, the asymptotic value obtained at the end of rehydration process is not the same as that obtained by the SLS method: approximately $10 \mu \mathrm{m}$. This can be explained by the fact that the detection limits of the two devices were not similar. For the granulomorphometer, the detection limit was $0.58 \mu \mathrm{m}$ (the size of one pixel defined on the device), slightly greater than the micelle size, whereas for the SLS method the detection limit was $0.05 \mu \mathrm{m}$. This means that only particles above $0.58 \mu \mathrm{m}$ were visible when using the granulomorphometer; all the particles inferior to this size are not taken into account in the particle population balance. Thus, the particle population balance became more and more inexact as the amount of fine particles increased. Indeed the digital image processing analysis delivered a Dv50 based only on the volume of larger particles, without taking into account all the finer particles (under the size detection limit). Unfortunately when the fine particles are numerous, they have a strong impact on the final value of Dv50.

These scatters are well known; the total rehydration time was evaluated by the SLS method. Digital images obtained by granulomorphometer are best used to discuss the solvent penetration and fragmentation process.

In addition to size, the granulomorphometer gave a particle distribution of the solution through recorded images: all the particles seen on acquisition were counted and the total number of particles in the sample calculated. This information was used to track the number of particles and provides information on the kinetics of fragmentation of the particles versus erosion. Since the 


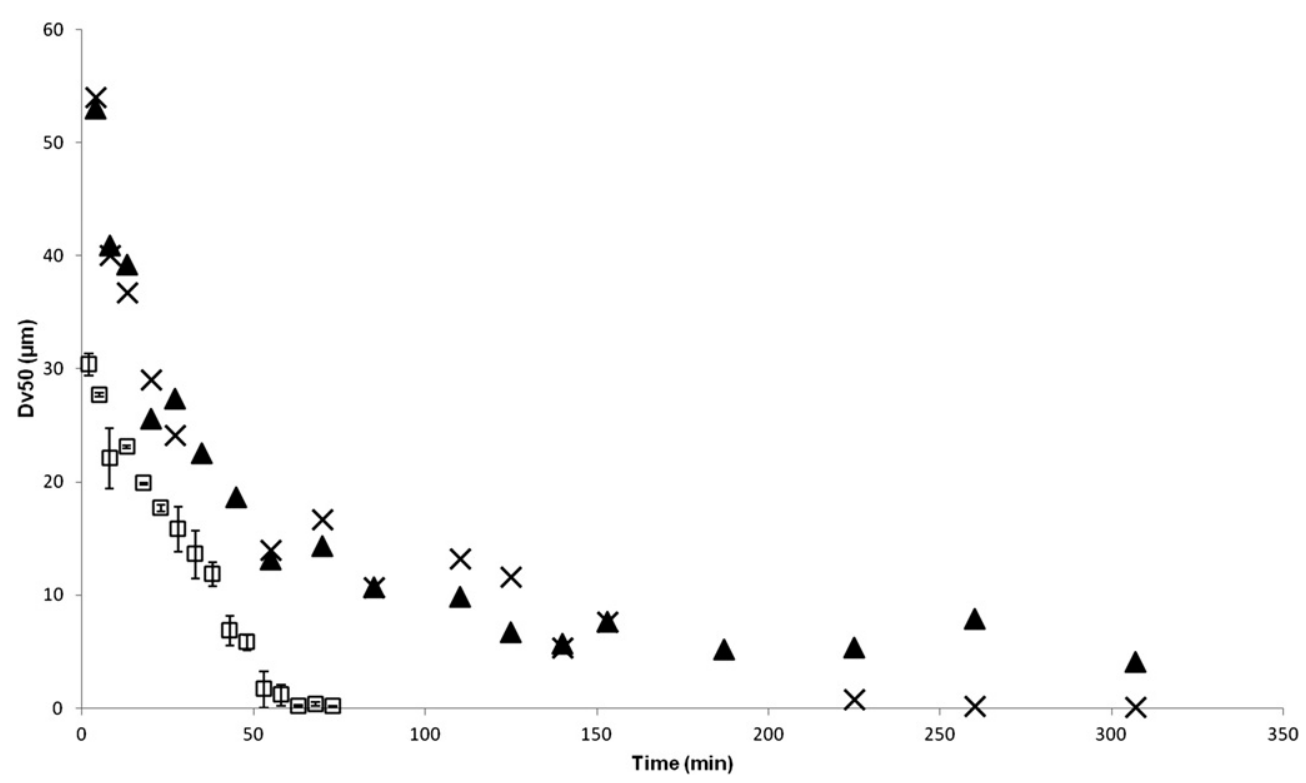

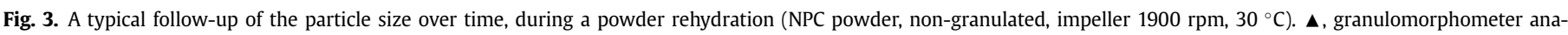
lysis; $\times$, SLS analysis; $\square$, native phosphocaseinate/whey protein ingredient powder SLS analysis, non-granulated, impeller 1700 rpm, $25^{\circ} \mathrm{C}$, with statistical analysis.

detection limit of granulomorphometer was greater than the casein micelles mean diameter, only particles with several agglomerated micelles could be analysed. The number of particles, combined with the Dv50, provided information on the state of fragmentation of particles and their kinetics of reduction in size.

Thus, the total number of particles increased at the beginning of rehydration as a result of fragmentation of larger particles. This number reached a maximum, balanced between fragmentation and release of single casein micelles, prior to decreasing until only partially soluble or insoluble particles remain.

\section{Results and discussion}

3.1. Qualitative analysis of rehydration curves: effects of dairy powders chemical composition, structure and stirring speeds on rehydration kinetics

Typical evolution of mean powder diameter (Dv50) over time after dispersion of the dairy powders in liquid is presented in Fig. 4.
Curves obtained at $25{ }^{\circ} \mathrm{C}$ under constant stirring conditions induced by the impeller 1 were similar to those of impeller 2 and at $30^{\circ} \mathrm{C}$. The three curves (square symbols) on the right side show the effect of stirring speed on rehydration kinetics and the two curves on the left (cross and triangular symbols) show the effect of granulation on rehydration kinetics at a given impeller rotational speed.

Irrespective of stirring speed, it can be observed that the rehydration curves obtained with NPC powders (square symbols) present all three stages, revealing that at least three successive mechanisms in milk powder reconstitution. The three stages are as follows.

Initially, mean particle size decreases sharply for a period of 10-15 min for NPC powder (generally, this step last 5-10\% of the total rehydration time of the powder). This first stage mainly corresponds to the wetting and dispersing of fragile particles, from Dv50 55-60 $\mu \mathrm{m}$ to 35-40 $\mu \mathrm{m}( \pm 5 \mu \mathrm{m}$, depending on the composition of powders). Fitzpatrick and Schober (2005) discussed in depth wettability, sinkability and relation to stirring speed. The next stage corresponds to a more gradual decrease in mean particle

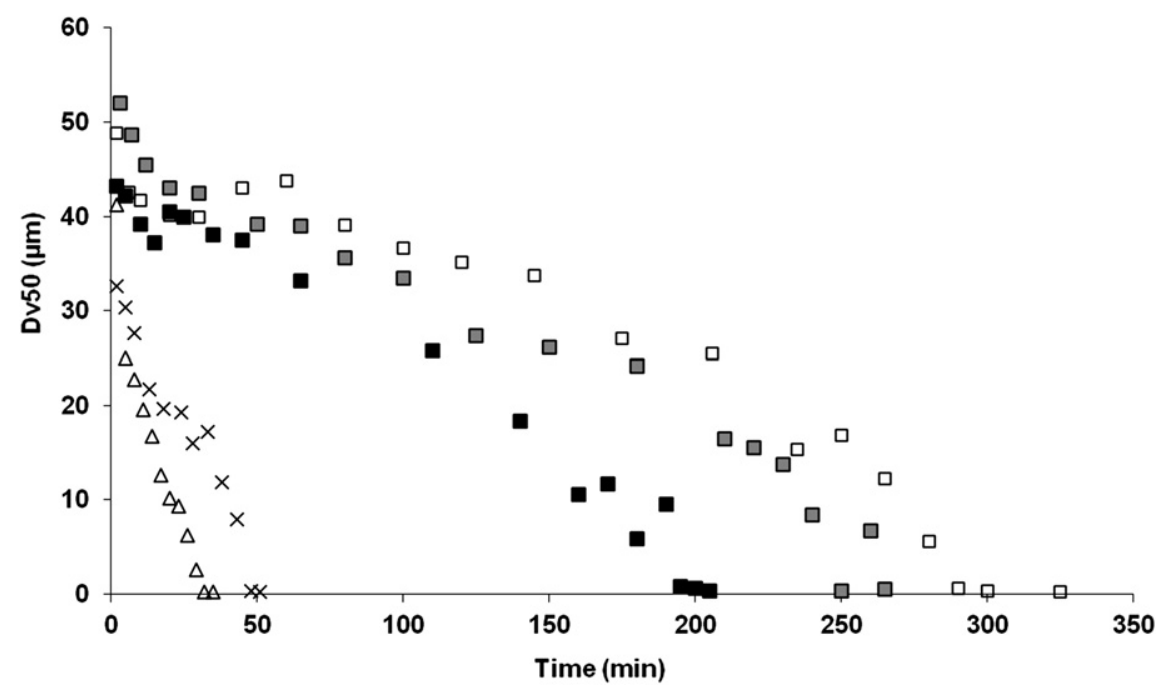

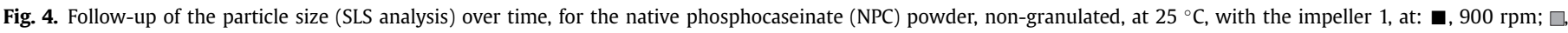

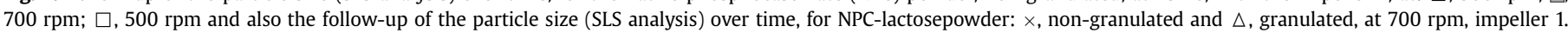


size through dissolution of the external layer of the solid by the liquid. This step was first observed by Hixon and Crowell (1931). This has also been observed more recently for mineral powders such as sodium hydroxide pellets (André, Richard, Le Page, Jeantet, \& Delaplace, 2012). The last step deals with final reduction of particle size. During this period, the rehydration kinetics are marked by a prompt acceleration, and mean particle size falls sharply from about 10 to $15 \mu \mathrm{m}( \pm 5 \mu \mathrm{m})$ to a particle size of $0.2 \mu \mathrm{m}$. The final part of rehydration suggests a sudden increase in fragmentation, as a fast decrease in cohesion between micelles is observed: forces are no longer sufficient to maintain particle shape. This differs from mineral powders where cohesion remains high enough to avoid particle fragmentation. Indeed for milk powder, the particle structure is an agglomerate of micelles and dissolution also includes fragmentation.

Analysis of Fig. 4 for a given powder (square symbols) shows that the higher the stirring speed the lower the processing time required to reach ultimate particle size. At $500 \mathrm{rpm}, 290 \mathrm{~min}$ is needed to reach a Dv50 of $0.2 \mu \mathrm{m}$, whereas $220 \mathrm{~min}$ is needed at $900 \mathrm{rpm}$. This phenomenon was observed for all the powders tested clearly revealing the effect of impeller rotational speed on dissolution rate. The positive influence of stirring speed on rehydration speed was observed throughout this study. On average (rehydration times of the different powders are reported in Table 2), when the stirring speed increases from $700 \mathrm{rpm}$ to $900 \mathrm{rpm}$, the total rehydration time is reduced by $25 \%$.

Irrespective of the powders and operating conditions (mixing system design, solvent and temperature), an increase in stirring speed implied an inversely proportional reduction of the total rehydration time.

The decrease in rehydration time with increasing stirring speed is well known (Hixon \& Crowell, 1931). Increasing mechanical agitation contributes to better dispersion of solids in liquids, by promoting turbulence around solid particle, favouring mass transfer and consequently rehydration and dissolution processes. In this study, the beneficial effect of agitation was linked directly to total rehydration time deduced from mean particle size distribution rather than through a mass transfer coefficient, as more commonly encountered in mixing scientific community.

Fig. 4 and Table 2 show that total dissolution times are very different in magnitude depending on the chemical composition of a given structure (Granulated or not). The cross and square symbols coloured in grey in Fig. 4 compare rehydration kinetics obtained for two non-granulated powders differing in chemical composition (NPC/lactose powder versus NPC powder) under the same stirring conditions $(700 \mathrm{rpm})$. The addition of lactose to NPC powders decreases the total rehydration time by a factor of 5.2 (260 min for the NPC powder and $50 \mathrm{~min}$ for the NPC/lactose powder).

This factor can increase to as much as 10 (For example, for granulated powders, rehydration time decreases from $750 \mathrm{~min}$ to $38 \mathrm{~min}$ when lactose is added to NPC, Table 2).

By comparing total rehydration time at similar stirring speed for different powders having the same structure, it can be seen that the addition of a compound with rapid dissolving properties (WPI, lactose) to a slow dissolving powder (NPC) accelerated the dissolution of the latter. One hypothesis may be that the creation of porosity with dissolution of the first compound facilitates the deconstruction of the casein micelle network by the created pores. The presence of lactose, which is a simple fast-dissolving sugar, helps water penetrate the core of the particle and dissolution is accelerated. Gaiani et al. (2010) reported that the presence of some ingredients (WPI, lactose) strongly affects the spacial distribution of chemical compounds at the surface of the powder, thus modifying rehydration time according to the dissolving behaviour of the latter. For example, the addition of WPI to NPC slightly increased the amount of fat on the surface of the particles. When lactose is added, half was located at the periphery and half in the core of particles.

Table 2 and Fig. 4 show total dissolution times are also strongly dependent on the structure (granulated or not) of powders. The comparison of cross symbols and triangles in Fig. 4 shows that for a given chemical composition under the same stirring conditions (700 rpm), different rehydration behaviours can be observed.

Table 2

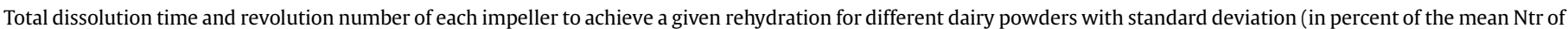
each group of speed; water temperature $25^{\circ} \mathrm{C}$ ).

\begin{tabular}{|c|c|c|c|c|c|c|c|c|}
\hline \multirow[t]{2}{*}{ Powder $^{\mathrm{a}}$} & \multicolumn{4}{|l|}{ Impeller 1} & \multicolumn{4}{|l|}{ Impeller 2} \\
\hline & Stirring speed (rpm) & $\begin{array}{l}\text { Total rehydration } \\
\text { time (min) }\end{array}$ & $\mathrm{Ntr}$ & $\begin{array}{l}\text { Standard } \\
\text { deviation (\%) }\end{array}$ & $\begin{array}{l}\text { Stirring } \\
\text { speed (rpm) }\end{array}$ & $\begin{array}{l}\text { Total rehydration } \\
\text { time (min) }\end{array}$ & $\mathrm{Ntr}$ & $\begin{array}{l}\text { Standard } \\
\text { deviation (\%) }\end{array}$ \\
\hline \multicolumn{9}{|c|}{ Native phosphocaseinate } \\
\hline \multirow[t]{3}{*}{ NG } & 500 & 290 & 145,000 & & 500 & & & \\
\hline & 700 & 260 & 182,000 & 15.5 & 700 & 640 & 448,000 & \\
\hline & 900 & 220 & 198,000 & & 900 & 420 & 378,000 & 12.0 \\
\hline \multirow[t]{3}{*}{ G } & 500 & 750 & 375,000 & & 500 & 870 & 435,000 & \\
\hline & 700 & 490 & 343,000 & 5.3 & 700 & 570 & 399,000 & 4.7 \\
\hline & 900 & 380 & 342,000 & & 900 & 450 & 405,000 & \\
\hline \multicolumn{9}{|c|}{ Native phosphocaseinate/whey protein isolate } \\
\hline \multirow[t]{3}{*}{ NG } & 500 & 80 & 40000 & & 500 & 108 & 54,000 & \\
\hline & 700 & 60 & 42000 & 14.7 & 700 & 90 & 63,000 & 8.0 \\
\hline & 900 & 35 & 31,500 & & 900 & 63 & 56,700 & \\
\hline \multirow[t]{3}{*}{ G } & 500 & 450 & 225,000 & & 500 & 450 & 225,000 & \\
\hline & 700 & 280 & 196,000 & 7.0 & 700 & 360 & 252,000 & 12.0 \\
\hline & 900 & 230 & 207,000 & & 900 & 220 & 198,000 & \\
\hline \multicolumn{9}{|c|}{ Native phosphocaseinate/lactose } \\
\hline \multirow[t]{3}{*}{ NG } & 500 & 65 & 32,500 & & 500 & 58 & 29,000 & \\
\hline & 700 & 50 & 35,000 & 5.5 & 700 & 55 & 38,500 & 19.6 \\
\hline & 900 & 35 & 31,500 & & 900 & 48 & 43,200 & \\
\hline \multirow[t]{3}{*}{ G } & 500 & 38 & 19,000 & & 500 & 43 & 21,500 & \\
\hline & 700 & 32 & 22,400 & 10.7 & 700 & 38 & 26,600 & 12.8 \\
\hline & 900 & 26 & 23,400 & & 900 & 30,5 & 27,450 & \\
\hline
\end{tabular}

\footnotetext{
a Abbreviations are: NG, non-granulated; G, granulated.
} 
Dissolution time is decreased by a factor of 1.6 when NPC/lactose powder is granulated: for the non-granulated powder the total rehydration time is $50 \mathrm{~min}$ rather than $32 \mathrm{~min}$.

Analysis of rehydration curves obtained for all the powders (Table 2) reveals that the granulation of the powder can modify total rehydration time by over $60 \%$.

It is generally considered that the granulation of powders facilitates the immersion stage since it decreases the surface to mass ratio. The granular structure also allows for rapid wetting of the particles and an easy dispersion in water. Non-granulated powders tend to stay on the free surface of the agitated liquid (Hall \& Hedrick, 1971). When the powder was granulated, the total rehydration time decreased for NPC and NPC/lactose powders but the effect of granulation is highly dependent on chemical composition. Depending on ingredients, it is shown here that granulation does not systematically improve rehydration. Indeed, when WPI is added to NPC, total rehydration time was $2-5$ times longer than for the corresponding non-granulated powder (60 min versus $280 \mathrm{~min}$ when the NPC/WPI powder is granulated; Table 2). This trend is somewhat expected in that the spray drying operation also strongly affects particle structure. Namely the number of path in the spray drying tower is radically different between granulated and nongranulated particles. The powders are subjected to a more or less severe thermal treatment that induces powder surface property changes. The principle of granulation is to recycle a part of the fine particles obtained to induce agglomeration. During this process path, the initial non-granulated particles are partially rehydrated and then re-dried several times.

It should be noticed that although the granulated particles size obtained by spray drying was about $200-250 \mu \mathrm{m}, 2$ min after the beginning of the rehydration process, granulated powders had already achieved a size equivalent to that of the corresponding nongranulated powder: Fig. 4 shows that at 2 min, the sizes are similar between the two structures. Consequently, the time required for granulated particles to split apart and reach the size of nongranulated particles was negligible compared with the change in total rehydration time (greater than $200 \mathrm{~min}$ in the case of NPC/WPI powder). This reinforces the fact that the time required for the separation of the grain does not alone explain the slower rehydration time, only a surface structure change would lead to such an important change (Mimouni, Deeth, Whittaker, Gidley, \& Bhandari, 2009).

Granulation should best be considered only if the wetting stage is limiting and the surface properties are not strongly modified by spray drying.

3.2. Quantitative analysis of rehydration curves: total rehydration time data obtained in various operating conditions and resulting processing relationship

The total dissolution time for the rehydration kinetics of different powders and impellers is given in Table 2. For each powder and impeller, the rehydration test was carried out at three stirring speeds (500, 700 and $900 \mathrm{rpm})$. In addition, the total revolution number Ntr reached by each impeller to achieve total rehydration was also calculated and reported in Table 2 . The results show that for a given powder and agitation system, Ntr is fairly constant, regardless of impeller speed. This indicates that for the range of $\operatorname{Re}$ numbers tested and solid/liquid fractions (for $50,000<\operatorname{Re}<100,000$ and $8 \%, w / w)$, the number of revolutions made by the agitator govern the rehydration curve. For the powders tested, the average variation in the total revolution number is $10.6 \%$ of Ntr (calculated from the variation with each powder, for three speeds obtained with a given configuration, Table 2), which is acceptable for process engineering purpose.

The fact that the rehydration time for various dairy powders was inversely proportional to impeller rotational speed is in agreement with the work of Jeantet et al. (2010), which was validated for one powder and one mixing system. In spite of using a mixing system similar to that of Jeantet et al. (2010), the rehydration times Ntr obtained with NPC powder were much higher than those obtained with the NPC powder tested. This is due to differences in spray drying conditions, chemical composition and ageing time of the powder.

In this work, such a process relationships were shown to be valid for other dairy powders (NPC, NPC/WPI, NPC/lactose) and mixing systems. Recently, André et al. (2012) measured dissolution time for non-food powder (highly soluble particles of sodium hydroxide) dispersed in aqueous solution, using similar approach. For another mixing system, the revolution number achieved by the

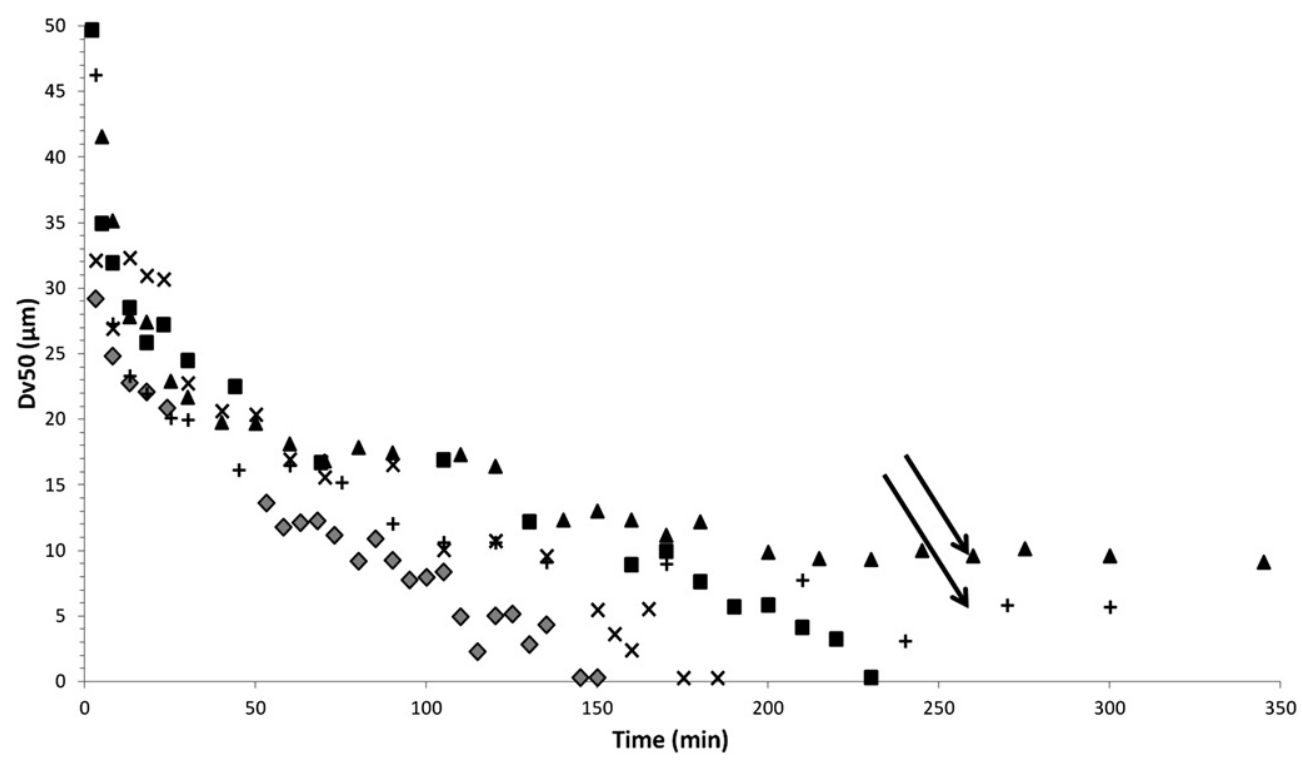

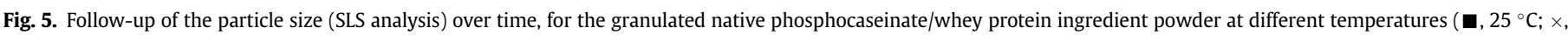
$30^{\circ} \mathrm{C} ;>, 35^{\circ} \mathrm{C} ;+, 37^{\circ} \mathrm{C} ; \boldsymbol{\Delta}, 40^{\circ} \mathrm{C}$ ) with impeller 1, at $900 \mathrm{rpm}$; arrows indicate aggregation. 
Table 3

Number of revolutions of the impeller to achieve total rehydration, for different type of impeller, temperature, and type of (non-granulated) native phosphocaseinate (NPC) powder.

\begin{tabular}{lllll}
\hline Reynolds & $\begin{array}{l}\text { Impeller } 1, \\
\mathrm{NPC}, 25{ }^{\circ} \mathrm{C}\end{array}$ & $\begin{array}{l}\text { Impeller 1, } \\
\text { NPC/lactose, } 25{ }^{\circ} \mathrm{C}\end{array}$ & $\begin{array}{l}\text { Impeller 2, } \\
\mathrm{NPC}, 30{ }^{\circ} \mathrm{C}\end{array}$ & $\begin{array}{l}\text { Impeller 1, } \\
\mathrm{NPC}, 30{ }^{\circ} \mathrm{C}\end{array}$ \\
\hline 54217 & 145,000 & 32,500 & 45,000 & 50,000 \\
75904 & 182,000 & 35,000 & 51,100 & 58,100 \\
9759 & 198,000 & 31,500 & 52,200 & 61,200 \\
\hline
\end{tabular}

Table 4

Laboratory power consumption of the agitator motor and the heating system, for two stirring speeds and two temperatures for non-granulated native phosphocaseinate powder.

\begin{tabular}{llllll}
\hline \multirow{2}{*}{$\begin{array}{l}\text { Temperature } \\
\left({ }^{\circ} \mathrm{C}\right)\end{array}$} & $\begin{array}{l}\text { Stirring } \\
\text { speed }(\mathrm{rpm})\end{array}$ & $\begin{array}{l}\text { Rehydration } \\
\text { time }(\mathrm{min})\end{array}$ & \multicolumn{2}{l}{ Power consumption $(\mathrm{J})$} \\
\cline { 4 - 6 } & & 58 & Stirring & Heating & Total \\
\hline 30 & 900 & 73 & 0.0182 & 0.263 & 0.281 \\
30 & 500 & 210 & 0.0140 & 0.306 & 0.320 \\
25 & 900 & 275 & 0.0660 & 0.447 & 0.513 \\
25 & 500 & 0.0527 & 0.586 & 0.638 \\
\hline
\end{tabular}

agitator governed the rehydration time and was almost independent of Reynolds number (range 5000-100,000). For the mineral powders used, of course the number of agitator revolution required to achieve dissolution was largely inferior to those observed for our dairy powder due to the use of fast-dissolving mineral particles instead of organic ones.

So this work shows that the number of revolutions made by the agitator is a generic law to ensure that a rehydration process is completed. It seems applicable to food and non-food particles which could be dissolute in water and various mixing systems.

Fig. 5 illustrates for an NPC/WPI powder the effect of temperature on reconstitution kinetics. Analysis of Fig. 5 reveals that from $25{ }^{\circ} \mathrm{C}$ to $35{ }^{\circ} \mathrm{C}$ the reconstitution process is faster with increasing temperature but at $37^{\circ} \mathrm{C}$, and above, aggregation occurs, disturbing the rehydration process. To avoid aggregation the reconstitution process should be carried out below $30{ }^{\circ} \mathrm{C}$ for all the powders. In parallel, preliminary results of reconstitution process (not shown here) with NPC non-granulated powder revealed that the dissolution process was extremely long at $20{ }^{\circ} \mathrm{C}$ (more than $6 \mathrm{~h}$ were required to reduce the mean particle diameter from $50 \mu \mathrm{m}$ to $30 \mu \mathrm{m})$. So, it was decided to investigate only temperature effect between $25^{\circ} \mathrm{C}$ and $30^{\circ} \mathrm{C}$.

The experimental impeller revolution number obtained for achieving total rehydration at $25^{\circ} \mathrm{C}$ and $30^{\circ} \mathrm{C}$, for the two mixing systems used is shown in Table 3 demonstrating that temperature influences dissolution time to a greater extent than stirring speed. It could be also observed. The process relationships (consistency of Ntr) remained valid at $25^{\circ} \mathrm{C}$ and $30^{\circ} \mathrm{C}$.

Consumption measurements made on the laboratory equipment during a rehydration test (for the electric motor of the
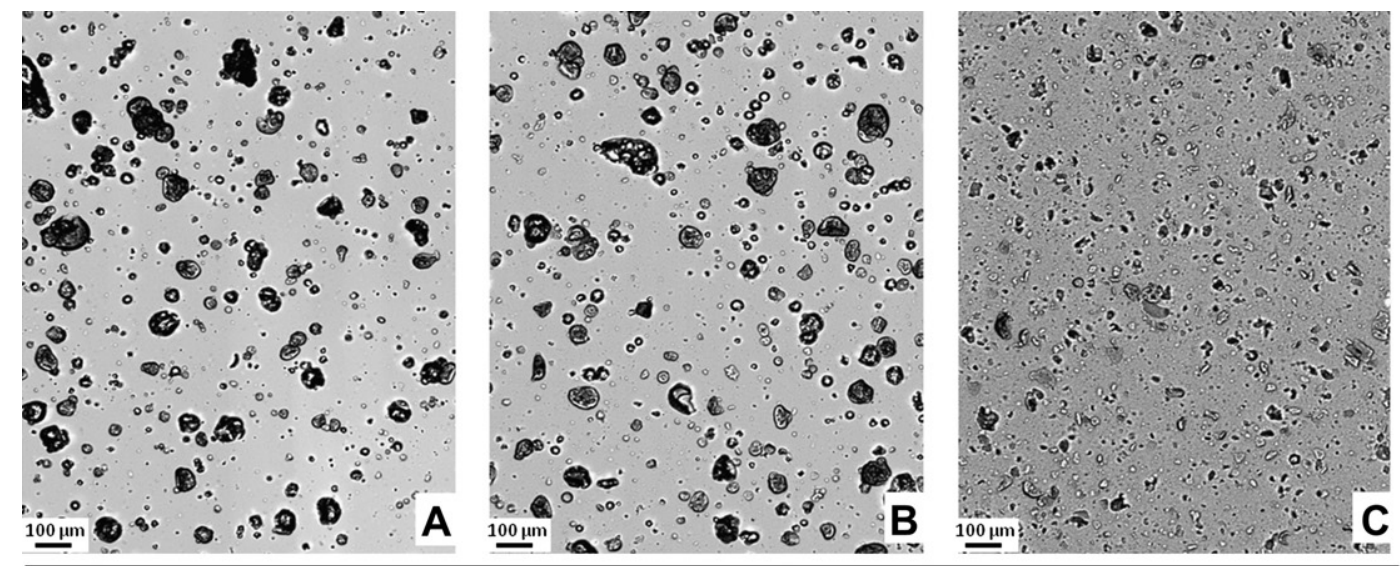

NPC

Impeller 1

$25^{\circ} \mathrm{C}, 900 \mathrm{rpm}$
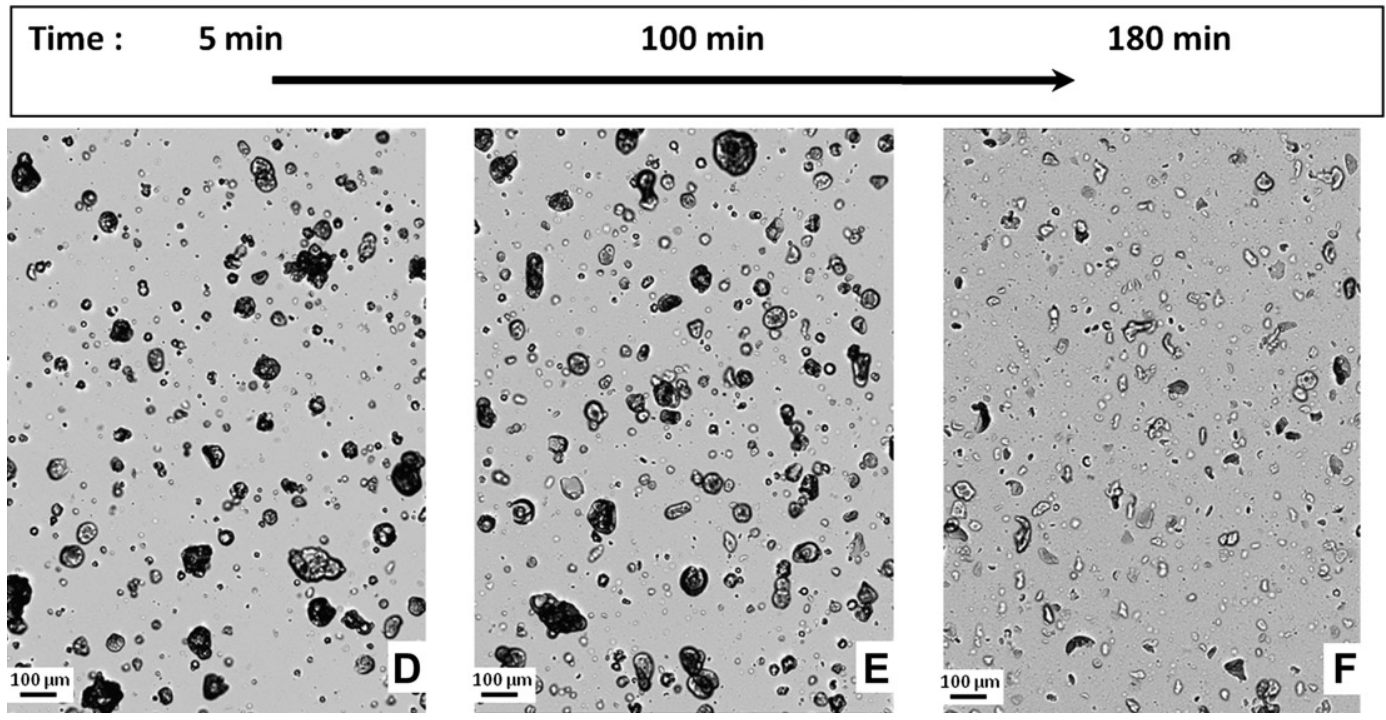

NPC

Impeller 2

$25^{\circ} \mathrm{C}, 900 \mathrm{rpm}$

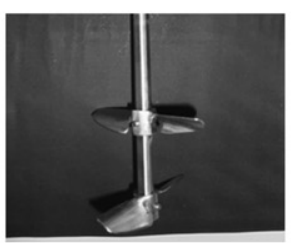

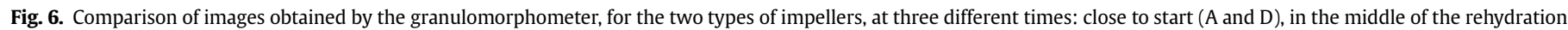
( $B$ and $E$ ), and near the end of rehydration ( $C$ and $F$ ). 
agitator and the heating system) are presented in Table 4 . The results shows that the total energy consumption for rehydration could be divided by a factor of 2 and total rehydration time by a factor of 4.7 by increasing temperature to $30^{\circ} \mathrm{C}$ and stirring speed to $900 \mathrm{rpm}$. In this case, a small increase in temperature and faster stirring speed have a positive impact on rehydration time and energy consumption. More knowledge is necessary on this topic to enable a manufacturer to adjust these parameters (temperature and stirring speed) and so reduce operating costs and increase process efficiency.

\subsection{Visualisation of solvent penetration and importance of impeller} effect and energy dissipation on fragmentation

Granulomorphometry provided online capture of powder dispersed in solvent and provided a tool for image processing. Thus, it was possible to track the evolution of powder appearance during rehydration and also provided observations on particle/solvent interactions and fragmentation.

Fig. 6 shows pictures obtained during rehydration of NG NPC with impellers 1 and 2 at $900 \mathrm{rpm}$ and $25^{\circ} \mathrm{C}$. The evolution of particles differed, depending on impeller type. With impeller 1 , the background darkened much faster and appeared darker than with impeller 2 after a long time (here $180 \mathrm{~min}$ ). This indicates that a larger amount of small particles were dispersed in water (less light passing through the cell); in addition, the average size was lower than the threshold of the granulomorphometer: $580 \mathrm{~nm}$. The Dv50 at 55 min was to $25 \mu \mathrm{m}$ for impeller 1 and $33 \mu \mathrm{m}$ for impeller 2 . These observations confirm that dissolution time was dependent on impeller type.

Fig. 7 is a representation of the evolution of particle size distribution obtained at three processing time of rehydration carried out with the two different impellers (same diameter and same stirring speed). Analysis of Fig. 7 shows that there are only slight differences between particle size distributions for the two impellers at $5 \mathrm{~min}$ after powder insertion. Note that for sake of clarity, it was chosen not to use a scale of frequency for the ordinate axis. The presence of a symbol on the horizontal line means that one or several particles exist in corresponding class size. The different symbols stand for the particle size distribution obtained with the different agitators. This representation allows the mechanical effect of the impeller to be followed on particles and rehydration kinetics; that is to say to follow the impact of the impeller geometry on the fragmentation. The particle distribution contains only few larger particles with impeller 2 compared with impeller 1 , showed by the presence of more symbols in the range 60-110 $\mu \mathrm{m}$. On the contrary, 55 min after powder insertion the difference in particle size distribution is more pronounced. The presence of several larger particles is observed with impeller 2 , while there are only smaller particles with impeller 1 . The size

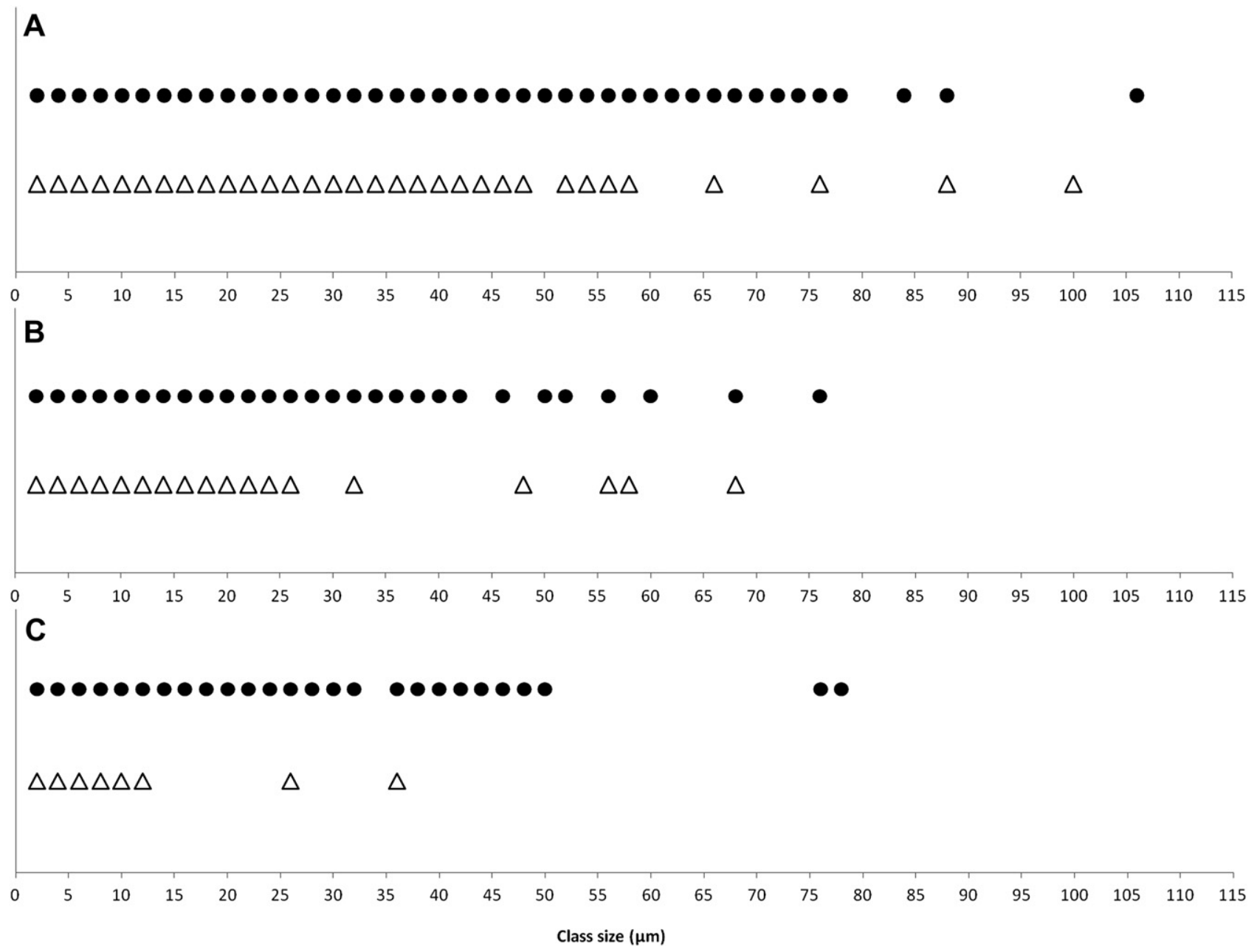

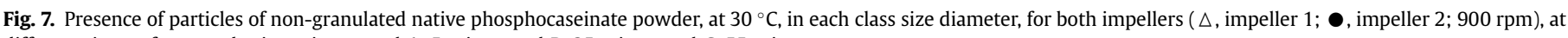
different times after powder insertion: panel A, 5 min; panel B, 35 min; panel C, 55 min. 

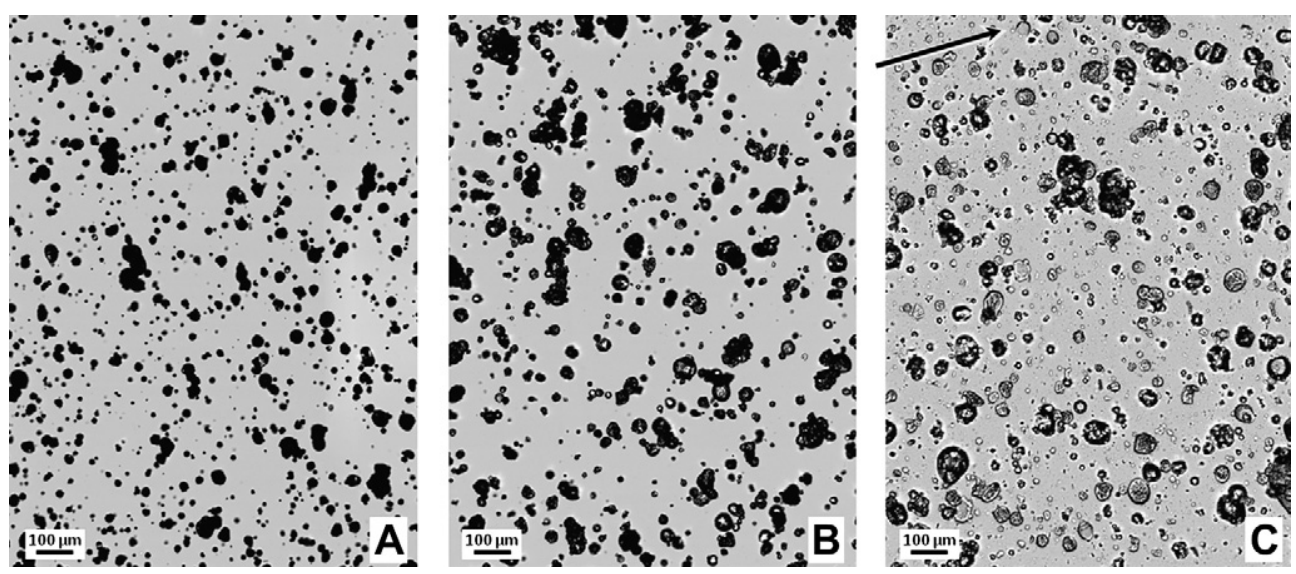

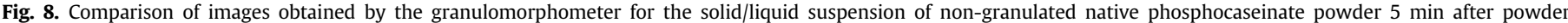
insertion $\left(25^{\circ} \mathrm{C}, 900 \mathrm{rpm}\right)$ in three types of solvent: A, ethanol; B, 50/50 ethanol/water mixture; C, water. Arrow indicates suggested sudden fragmentation of the particles.

distribution of impeller 1 varies from 0 to $15 \mu \mathrm{m}$ with few particles around $25 \mu \mathrm{m}$ and $35 \mu \mathrm{m}$ whereas for impeller 2 , the size distribution goes from 0 to $50 \mu \mathrm{m}$, with some particles around 75-80 $\mu \mathrm{m}$. This means that impeller 1 provided better fragmentation and/or dissolution of large particles and favoured small sized particles. Note that $90 \%$ of the total particle number had a mean diameter of less than $6 \mu \mathrm{m}$ (not represented to clarify the diagram).

This highlights the influence of the mixing equipment design on the dissolution process. Impeller 1 with its 6 -pitched blades had an important local energy dissipation promoting the fragmentation of large particles, while the energy dissipation induced by impeller 2 concerned the whole liquid phase, favouring particle circulation in the tank on the detriment of fragmentation.

Impeller 2 provided a better insertion of the powder by suction phenomena (size lower at the beginning of the dissolution), but its overall energy dissipation decreases its fragmentation efficiency and thus increases the time required for complete dissolution.

Image analysis provided other observations: i.e., the entry or not of the solvent into the powder particles. Indeed, granulomorphometer light calibration was always realised on the solvent, with an associated grey level of 200. Consequently, whatever the solvent nature (pure water, pure ethanol or mixtures of water and ethanol) an important contrast exists at the first stage of dispersion between solvent and powder before solvent penetration in the particle. On the other hand, when solvent penetrates inside the particle all along the rehydration process, this contrast tends to decrease immediately.

Fig. 8 shows pictures captured by the granulomorphometer for the NPC non-granulated powder suspension in three different solvents (water, a 50/50 water/ethanol mix and absolute ethanol) 5 min after the powder insertion. In absolute ethanol, the particles stay very dark with no size reduction all along the rehydration process. Conversely, in pure water and in 50/50 water/ethanol the particles appear immediately clearer. In pure water, this phenomenon observed is of course more important.

The fact that contrast between particle and solvent is very pronounced during all the rehydration process when ethanol is used as solvent can be explained by the fact that ethanol does not succeed in penetrating inside the core of particle. However, when an amount of water is present in the solvent (pure water or mixture of water and ethanol), penetration of solvent inside the particles is allowed, explaining the contrast decrease with the advancement of rehydration process. This highlights the potential of the granulomorphometer in identifying solvent interactions with the particles. Rehydration of the particles occurs not only from the particle shell, but also from water transfer to the core and departure of casein micelles from the inside. Image analysis shows some particles at the end of rehydration with only a peripheral shell, the inside of the particle appearing empty (Mimouni, Deeth, Whitaker, Gidley, \& Bhandari, 2010). This could explain the sharp drop in size below a threshold (generally $15 \mu \mathrm{m}$, observed on many size curves), and suggests a sudden fragmentation of the particles, emptied of their contents (arrow on Fig. 8C). The structure is no longer strong enough to maintain shape; the forces exercised by the agitator become higher leading to fragmentation.

\section{Conclusions}

This work illustrates that many parameters impact dairy powders rehydration: mixing equipment design, operating conditions (stirring, temperature) and chemical composition of powder.

Analysis of rehydration curves with regards to powder structure revealed that granulation is not always a pre-requisite to acceleration of the rehydration process, depending on wettability versus total rehydration time.

Analysis of rehydration curves shows that the presence of certain compounds such as lactose/and WPI facilitate rehydration process kinetics, by favouring solvent penetration.

In general the number of agitator revolutions required to achieve a desired degree of rehydration is constant and independent of impeller rotational speed. This work enlarged the domain of validity of relationships first proposed by Jeantet et al. (2010). Comparison of rehydration times achieved at various impeller speeds and temperature conditions confirms that rehydration process is more sensitive to temperature, than impeller speed. Proper temperature minimises the mechanical energy necessary.

Granulomorphometer analysis was found to be an interesting tool to track solvent transport and to understand associated mechanisms of fragmentation, highlighting dynamic structure modifications.

\section{Acknowledgements}

The authors are indebted to the scientific committee of CNIEL Recherche (Paris, France) for stimulating discussions and financial support. We wish to thank Dr David F. Perry for his proofreading and corrections of the English language.

\section{References}

André, C., Richard, B., Le Page, J. F., Jeantet, R., \& Delaplace, G. (2012). Influence of mixing system design and operating parameters on dissolution process. Chemical Engineering and Technology, 35, 247-254. 
Aneja, R. P. (1990). Equipment for recombination. In IDF special issue 9001, recombination of milk and milk products conference (pp. 186-195). Brussels, Belgium: International Dairy Federation.

Aschaffenburg, R., \& Drewry, J. (1959). New procedure for routine determination of the various non casein proteins of milk. In. Proceedings of the 15th international dairy congress, Vol. 3 (pp. 1631-1637). Brussels, Belgium: International Dairy Federation.

Cayot, P., \& Lorient, D. (1998). Les propriétés d'hydratation des protéines. In Structures et technofonctions des protéines du lait, Arilait Recherches, Tec E Doc (pp. 209-227). Paris, France: Lavoisier.

Fitzpatrick, J. J., \& Schober, C. (2005). Effect of vortex formation on powder sinkability for reconstituting milk powders in water to high solids content in a stirred-tank. Journal of Food Engineering, 71, 1-8.

Gaiani, C., Banon, S., Scher, J., Schuck, P., \& Hardy, J. (2006). The dissolution behaviour of native phosphocaseinate as a function of concentration and temperature using a rheological approach. International Dairy Journal, 16, 1427-1434.

Gaiani, C., Morand, M., Sanchez, C., Arab Tehrany, E., Jacquot, M., Schuck, P., et al. (2010). How surface composition of high milk proteins powders is influenced by spray-drying temperature. Colloids and Surfaces B: Biointerfaces, 75, 377-384.

Gaiani, C., Schuck, P., Scher, J., Desobry, S., \& Banon, S. (2007). Dairy powder rehydration: influence of protein state, incorporation mode, and agglomeration. Journal of Dairy Science, 90, 570-581.

Hall, C. W., \& Hedrick, T. I. (1971). Drying of milk and milk products (2nd ed.). Westport, CN, USA: Avi Publishing Company Inc.

Hixon, A. W., \& Crowell, J. H. (1931). Dependence of reaction velocity upon surface and agitation: I - theoretical consideration. Industrial and Engineering Chemistry, 23, 923-931.

Jeantet, R., Ducept, F., Dolivet, A., Méjean, S., \& Schuck, P. (2008). Residence time distribution: a tool to improve spray-drying control and product quality. Dairy Science and Technology, 88, 31-43.
Jeantet, R., Schuck, P., Six, T., Andre, C., \& Delaplace, G. (2010). The influence of stirring speed, temperature and solid concentration on the rehydration time of micellar casein powder. Dairy Science and Technology, 90, 225-236.

Jensen, G. K., \& Nielsen, P. (1982). Reviews of the progress of dairy science: milk powder and recombination of milk and milk products. Journal of Dairy Research, 49, 515-544.

King, N. (1966). Dispersibility and reconstitutability of dried milk. Dairy Science and Technology, 28, 105-118.

Mimouni, A., Deeth, H. C., Whittaker, A. K., Gidley, M. J., \& Bhandari, B. R. (2009). Rehydration process of milk protein concentrate powder monitored by static light scattering. Food Hydrocolloids, 23, 1958-1965.

Mimouni, A., Deeth, H. C., Whitaker, A. K., Gidley, M. J., \& Bhandari, B. R. (2010) Investigation of the microstructure of milk protein concentrate powders during rehydration: alterations during storage. Food Hydrocolloids, 93, 463-472.

Petit, A., Herbig, A.-L., Moreau, A., Le Page, J.-F., Six, T., \& Delaplace, G. (2012). Granulomorphometry: a suitable tool for identifying hydrophobic and disulfide bonds in $\beta$-lactoglobulin aggregates. Application to the study of $\beta$-lactoglobulin aggregation mechanism between 70 and $95{ }^{\circ} \mathrm{C}$. Journal of Dairy Science, 95 4188-4202.

Pierre, A., Fauquant, J., le Graet, Y., Piot, M., \& Maubois, J. L. (1992). Préparation de phosphocaséinate natif par microfiltration sur membrane. Lait, 72, 461-474.

Rowland, S. J. (1938). The determination of nitrogen distribution in milk. Journal of Dairy Research, 9, 42-46.

Schubert, H. (1993). Instantization of powdered food products. International Chemical Engineering, 33, 28-44.

Schuck, P. (2002). Spray drying of dairy products: state of the art. Lait, 82, 375-382.

Schuck, P., Piot, M., Mejean, S., Le Graët, Y., Fauquant, J., Brulé, G., et al. (1994) Déshydratation par atomisation de phosphocaséinate natif obtenu par microfiltration sur membrane. Lait, 74, 375-388.

Siepmann, J., \& Siepmann, F. (2008). Review: mathematical modelling of drug delivery. International Journal of Pharmaceutics, 364, 328-343. 